\title{
A combined petrological and numerical approach to investigate basaltic Plinian eruptions at Masaya Caldera, Nicaragua
}

\author{
EMILY C BAMBER ${ }^{1}$, FABIO ARZILLI ${ }^{1}$, MIKE R \\ BURTON $^{1}$, MARGHERITA POLACCI $^{1}$, GIUSEPPE LA \\ SPINA $^{1}$, MATTIA DE' MICHIELI VITTURI ${ }^{2}$, MARGARET E \\ HARTLEY ${ }^{1}$, MAURIZIO PETRELLI ${ }^{3}$, JONATHAN \\ FELLOWES $^{1}$, DAVID CHAVARRÍA ${ }^{4}$ AND JOSÉ \\ ARMANDO SABALLOS ${ }^{4}$ \\ ${ }^{1}$ University of Manchester \\ ${ }^{2} \mathrm{INGV}$ \\ ${ }^{3}$ University of Perugia \\ ${ }^{4}$ INETER \\ Presenting Author: emily.bamber@postgrad.manchester.ac.uk
}

Due to the low viscosity of basaltic magma, explosive Plinian eruptions are rare at basaltic volcanoes. However, syn-eruptive processes such as crystallisation and vesiculation can drive the fragmentation of basaltic magma within volcanic conduits. The Las Sierras-Masaya volcanic system, Nicaragua, is an unusual volcano which has produced multiple basaltic Plinian eruptions over the past 60,000 years. Today, Masaya caldera is characterised by degassing and eruptions of much lower explosivity. Understanding the cause of this highly explosive activity is crucial for hazard assessments.

We combine petrological techniques with a numerical modelling approach to first constrain and then investigate the pre- and syn-eruptive conditions of two basaltic Plinian eruptions: The Fontana Lapilli (60 ka) and The Masaya Triple Layer $(2.1 \mathrm{ka})$. We incorporate our data on major element chemistry, volatile concentrations and pre-eruptive temperature and pressure into a numerical sensitivity analysis. We find that the conditions which may have promoted a basaltic Plinian eruption are a pre-eruptive storage temperature $<1100{ }^{\circ} \mathrm{C}$ and a high total crystal content.

Petrological evidence indicates that the Fontana Lapilli magma stagnated at shallow depth within the crust, cooling and crystallising a mush at temperatures $<1100{ }^{\circ} \mathrm{C}$. Our simulations of magma ascent demonstrate that once the eruption is triggered, magma ascends to the surface within minutes, with rapid syneruptive crystallisation driving brittle magma fragmentation within the conduit, producing a Plinian eruption. 